Research, part of a Special Feature on Twenty Years of Community Forestry in Cameroon: Opportunities and Challenges for Sustainable Development

\title{
Evolution of community forestry in Cameroon: an innovation ecosystems perspective
}

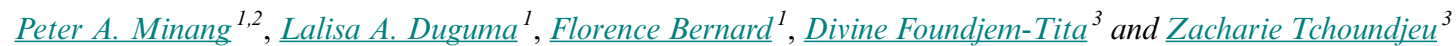

\begin{abstract}
Cameroon introduced community forestry (CF) in 1994 as a means of improving community engagement in forest management, enhancing forest conservation, and reducing poverty for forest-dependent people. More than 20 years on, reflection on uptake, conceptual evolution, and innovation is necessary to understand how best community forests can contribute to Cameroon's post-2015 sustainable development goals. We investigate, review, and reflect on how community forestry has evolved from an innovation ecosystem perspective, with a view to enhancing innovations and performance. Interest and momentum in community forestry remains strong in Cameroon, with the number of community forests growing, reaching 430 and covering 1.7 million ha ( $7 \%$ of total forest area). Major innovations identified are the introduction of pre-emption rights and steps toward sustainable forest management (ban on industrial logging, development of certification standards, and the introduction of the environmental notice in lieu of a full environmental impact assessment for $\mathrm{CF}$ activities). Little or no innovation is registered in areas related to forest enterprise (i.e., products and services value chains) and in terms of practicing sustainable forest management. Evidence suggests that knowledge generated directly feeds innovation. Coincidentally, areas for which little progress was made (enterprise and sustainable practices) also recorded few publications, suggesting that partnerships aimed at improving knowledge generation and sharing could help catalyze innovation. Other options for unlocking innovations within community forestry discussed include: enhancing intercommunity forest and private sector community forests partnerships and collaboration, increased capacity development and capital investments, and deploying incentives (financial and nonfinancial). Together these options can potentially transform community forestry in Cameroon.
\end{abstract}

Key Words: Cameroon; community forestry; evolution; innovation ecosystems

\section{INTRODUCTION}

Community forestry $(\mathrm{CF})$ can be defined as forest management in which communities manage and use forests, often with some form of legal authority to do so, and it is primarily driven by local community benefits and ecological sustainability goals (Arnold 2001, Ribot 2002). Community forestry is one of the fastest growing forms of forest management. Since its emergence in the 1970 s, it has grown tremendously with communally managed forests being the main source of livelihood for more than 1.2 billion people (Agrawal et al. 2008). Community forestry has been practiced in several countries around the world including Mexico, Nepal, Philippines, Tanzania, Kenya, and others. It was founded largely as an alternative to state-managed conservation. It was assumed that shifting the management of forests from state to local communities could result in more sustainable management of forests, if communities found it in their interests to conserve them (Maryudi et al. 2012), while also contributing significantly to social and economic development.

Charnley and Poe (2007) reviewed progress in the field of community forestry using four examples from the Americas, i.e., Canada, United States, Mexico, and Bolivia and revealed that although $\mathrm{CF}$ remained a promising concept for achieving conservation and development, significant gaps remained between theory and practice. Devolution of responsibility and decision making remained partial, local management resulted in the delivery of ecological benefits in many cases, but hardly any socioeconomic or livelihood benefits occurred. Charnley and Poe concluded that there might be a need for innovative anthropological approaches to help bridge the gaps between $\mathrm{CF}$ theory and practice.
Ojha and Kanel (2005) also reviewed 25 years of community forestry in Nepal based on inputs from more than 200 stakeholder contributions through 82 papers based on proceedings from a national workshop. They found that community forest conditions had improved overall compared to other forests; the participation and contributions of women had increased significantly; and the legal and institutional framework had been well developed. On the downside, they highlighted the general lack of evidence of any livelihood improvement as a result of CF; a deficit in the distribution of community forests around the country with the middle hills hosting most CFs whereas the Terai and high hill regions had very few; inequities in control, with representation in decision making dominated by wealthier families and therefore also benefiting them more; need for improvements in processes; and also a more diversified enterprise-driven approach beyond timber and nontimber forest products (with a total economic value perspective).

In a global systematic review of key success factors for community forestry, Baynes et al. (2015) identified five key factors. These are: (1) government support for community forest groups, (2) intracommunity forest groups (CFG) governance, (3) material benefits, (4) socioeconomic status and gender-based inequality, and (5) secure property (land and tree) rights. They highlighted that intra-CF governance can be directly improved through social cohesion, capacity building, and the participation of all social groups. Social cohesion, which is a significant determinant of good CF governance, depends on socioeconomic and gender equality, and capacity building. Tree and tenure rights give community forest members harvest rights through devolution. This opens the way to access rights; when community forest members effectively enjoy these rights, they are motivated to

${ }^{1}$ World Agroforestry Centre, Nairobi, Kenya, ${ }^{2}$ ASB Partnership for the Tropical Forest Margins, Nairobi, Kenya, ${ }^{3}$ World Agroforestry Centre, West and Central Africa Regional Office, Yaoundé, Cameroon 
participate in community forests decision-making processes and activities, thus improving $\mathrm{CF}$ governance. They also observed in the meta-analysis of 46 empirical studies that technological and material assistance influences land and forest productivity.

Berkes (2009) highlighted the importance of knowledge generation, bridging organizations, and social learning to the emergence of adaptive comanagement in a review of 20 years of comanagement. He noted that comanagement can be considered a knowledge partnership in which coordination of tasks such as accessing resources, bringing together different actors, building trust, resolving conflict, and networking are necessary for joint social learning, problem solving, and possibly innovation. Through colearning, comanagement processes can mature into adaptive comanagement. Given that comanagement is a power and responsibility sharing arrangement between government and local resource users, these findings could apply to community forestry actor interactions. Nightinghale (2005) pointed out the need for mutual respect and consideration in the interaction between professional forestry from government forestry technical support and local knowledge in the management of community forests in Nepal. The risk of the former undermining the latter is real in specific contexts, with potentially negative consequences on community forestry outcomes.

We are looking back at 20 years of community forestry in Cameroon. Since its introduction, a comprehensive structured review has not been done. A reflection on uptake, conceptual evolution, and innovation is necessary to understand how best community forests have achieved the objectives for which they were created, and how they could potentially contribute to Cameroon's post 2015 sustainable development goals. Cameroon is one of many countries that harbor parts of the Congo Basin's forest in Central Africa. Like most countries in Central Africa, many people depend on forests for a living, with timber contributing about $12 \%$ of the gross domestic product (GDP).

Three main review-type reports have punctuated the 20-year history of $\mathrm{CF}$ in Cameroon: (1) a stocktaking report by government in 2003 on progress made, focusing on general aspects related to policy frameworks (MINEF 2003); (2) a commissioned report in 2006 that reviewed progress on the institutional side (MINFOF and CARFAD 2006); and (3) a Tropenbos status report that took stock of $\mathrm{CF}$ and communal forest advances in Cameroon including some examples of implementation (Cuny et al. 2011).

However, all of these reports do not sufficiently address a systems perspective with a view to improving innovation. We seek to investigate, review, and reflect on how community forestry has evolved from an innovation system perspective with respect to meeting the objectives for which they were created. Specific questions we seek to answer are: What are the main features of the $\mathrm{CF}$ innovation ecosystem in Cameroon? How has community forestry evolved over the past 20 years in Cameroon? What significant innovations have been recorded in $\mathrm{CF}$ in Cameroon and with what impacts? And how can the CF innovation ecosystem attributes be used to make CF more effective in delivering the objectives? It is hoped that insights into how innovations happen within community forestry will enable better policy support or leadership actions.

\section{INNOVATION ECOSYSTEMS: THE ANALYTICAL FRAMEWORK}

Innovation ecosystem comprises a network of critical actors interacting in a given geographical or sectoral setting to apply knowledge and information, producing innovations to address socioeconomic problems or needs (Mytelka 2000, Essegbey and Ofori-Gyamfi 2012). Innovation can be broadly defined as a new product or service, or as a significant change in the technological or organizational process in the system under consideration. Key characteristics of an innovation process include, the critical actors/entities, the interactions and relationships between actors, the knowledge and information flows, and the context of innovation (e.g., policies, culture, etc.).

We purposefully use "innovation ecosystems" to represent dynamic collaborative networks of people and organizations that emerge around initiatives with an innovation objective, with collaboration, and who value cocreation and self-governance as distinguishing characteristics (Smorodinskaya et al. 2017). This is different from "innovation systems" wherein guidance from central authority or external intervention shapes innovation (Smorodinskaya et al. 2017). Innovation ecosystems thinking is relevant for $\mathrm{CF}$ in Cameroon given the dispersed and networked nature of community forests in the country (Piabuo et al. 2018).

Rametsteiner and Weiss (2006) applied innovation systems' thinking in examining empirical realities of forest policy innovation processes in seven central European countries. Although innovation systems' thinking had been applied to hightech sectors, it had not been previously used in a relatively lowtech sector such as forestry. They attempted to link a classic linear innovation model used in the wood processing industry, (i.e., at a firm level) to broader government policy levels. Although innovation at a firm level requires linear or mechanical inputoutput efficiency changes, at the policy level innovation can be more complex, often requiring multiple actor negotiations to forge synergies and change. The broader system-level functions of an innovation system include: (1) to reduce uncertainties by providing information; (2) to manage conflicts and cooperation; and (3) to provide pecuniary and nonpecuniary incentives. They concluded that innovation system approaches are quite relevant to understanding and promoting innovation in forestry.

Smith et al. (2005) provided an overview of the governance of sustainable socio-technical transitions through the lens of innovation systems' thinking. They recognized that firms that bring about innovations in environmental management are embedded in wider social and economic systems and hence context and agency would greatly influence innovations. They introduced notions of regime membership, resource interdependencies, and actor expectations as key elements of transformation processes, confirming that the power to affect change depends on these three variables.

A literature review was applied in this study. Literature, both gray and peer reviewed, from 1994 to February 2017, was sought and assembled from Google Scholar, Science Direct, Web of Science, and Scopus, using keywords and their combinations to identify candidate papers. The keywords used for the literature search included: community forest, community forestry, communitybased forest management, and Cameroon. We also used French keywords such as foresterie communautaire, forêts communautaires, 
and Cameroun. This process yielded a total of 90 studies that dealt with community forestry in Cameroon. Out of this number, 36 studies were peer-reviewed publications and 54 were nonpeerreviewed publications. Nine of the nonpeer-reviewed publications were not included in the analysis because of a lack of information regarding the year of publication for four of them and not finding the actual publication for five of them. The analysis was therefore run with 81 studies.

We focused on two main dimensions in the review of literature. First, we identified any evidence of innovations in terms of significant changes in technological or institutional processes, or the introduction of new products or services. We also sought evidence of descriptions or characterizations of the same. Secondly, we looked for evidence on four variables that could possibly explain innovation dynamics and/or the lack of innovations including: knowledge and information available in the $\mathrm{CF}$ subsector; resources available in the $\mathrm{CF}$ subsector; partnerships, alliances, and interactions; and incentives.

\section{EVOLUTION OF COMMUNITY FORESTRY (CF) OVER THE LAST 20 YEARS}

Community forest is defined within the 1994 law in Cameroon as "that part of non-permanent forest estate (not more than 5000 ha) that is the object of an agreement between government and a community in which communities undertake sustainable forest management for a period of 25 years renewable" (MINEF 1998:9). Community forestry was introduced as a means of improving community engagement in forest management, enhancing forest conservation, and reducing poverty for forestdependent people.

For communities to be attributed a community forest, they need to fulfil a number of conditions including (but not limited to): constituting a legal entity and appointing a manager who shall represent them in negotiations with government in matters of community forestry (entity could be a common initiative group, an economic interest group, a cooperative, or an association); delineate and map the intended community forest area; develop and submit a simple management plan for the first 5 years (see Manual of Procedures for details; MINEF 1998).

\section{Historical timeline}

Community forestry in Cameroon was born through a long process of forest reforms that started in 1988 with the development of the Tropical Forestry Action Plan. The reform process had five broad national forest policy objectives and corresponding strategies for their achievement (Government of Cameroon 1993, 1995). These were: (1) to safeguard/protect the forest heritage, environment, and biodiversity; (2) strengthen the participation of local population in forest management and conservation so that forestry can contribute to raising their living standards; (3) enhance forest resources and their contribution to the national gross domestic product while preserving productivity; (4) ensure the regeneration of forest resources through plantations to perpetuate potential; and (5) revitalize the forest sector by setting up an efficient institutional framework.

The process resulted in the revision of the forest law of 1981. A new forest law was enacted and promulgated in 1994 (Law No. 94-1 of 20 January 1994). The prime minister signed a corresponding implementation decree specifying details of the new law in 1995 (No. 95-531-PM of 23 August 1995). Together, the 1994 law and its implementation decree laid out a new classification of forests, logging rights, and conditions and norms for management of forests in Cameroon. Community forestry was one of the new management units created through the revision process (Ekoko 2000, Djeumo, 2001). A historical timeline of community forestry evolution is shown in Figure 1. The bottom part of the figure represents a timeline of legal and administrative instruments, while the top part represents a timeline of selected institutions and events that have shaped the development of community forestry in Cameroon.

\section{Evolution of community forestry in numbers}

Figures $2 \mathrm{a}$ and $2 \mathrm{~b}$ show the numerical evolution of community forests in terms of total number of community forests, total area of community forests, as well as community forests with final management agreements, provisional management agreements, and those that have obtained annual exploitation certificates (CEA). The figures show a spike in number and area of community forestry between 2006 and 2011. However, the number of community forests with final management agreements quasi stagnated between 2010 and 2016, whereas numbers of CFs with provisional management agreements have dominated since 2010. The number of community forests with valid simple management plans have also been significantly reduced since 2010 because of a lack of start-up funds, knowledge, and institutional capacity to make use of the temporary opportunity to exploit the forest and raise the necessary funds to move forward with procedures.

\section{THE COMMUNITY FORESTRY INNOVATION ECOSYSTEM IN CAMEROON}

The community forestry innovation ecosystem looks at three key attributes: the actors' landscape, knowledge and information provision, and project actions and interventions.

\section{Community forestry actors' landscape}

The most important characteristic in any innovation ecosystem is its set of main actors, their roles, and their interactions (Mytelka 2000). These relationships are determined by the environment, context factors, and stimuli. Figure 3 shows the various critical actors in community forestry in Cameroon and the set of contextual variables, external and internal, that shape relationships, actions, and therefore innovations. By understanding the dynamics around these actors and their interactions, we can better understand innovation pathways and dimensions in community forestry in Cameroon.

Main actors in community forestry in Cameroon include, the Cameroon Ministry of Forestry and Wildlife (MINFOF), NGOs, and community-based organizations (civil society), community forest entities and local communities, community forestry networks, timber companies, universities, and consultants. Table 1 summarizes the roles and responsibilities of each of these actors.

The Cameroon Ministry of Forestry and Wildlife is perhaps the one actor that has evolved the most since the creation of community forestry. This ministry changed from the Ministry of Environment and Forestry (MINEF) to MINFOF. In the beginning, a community forestry unit was created with full responsibility for community forestry related matters. Then it was later upgraded to a subdirectorate of community forestry. They 
Fig. 1. Timeline showing key highlights of community forestry (CF) development in Cameroon.

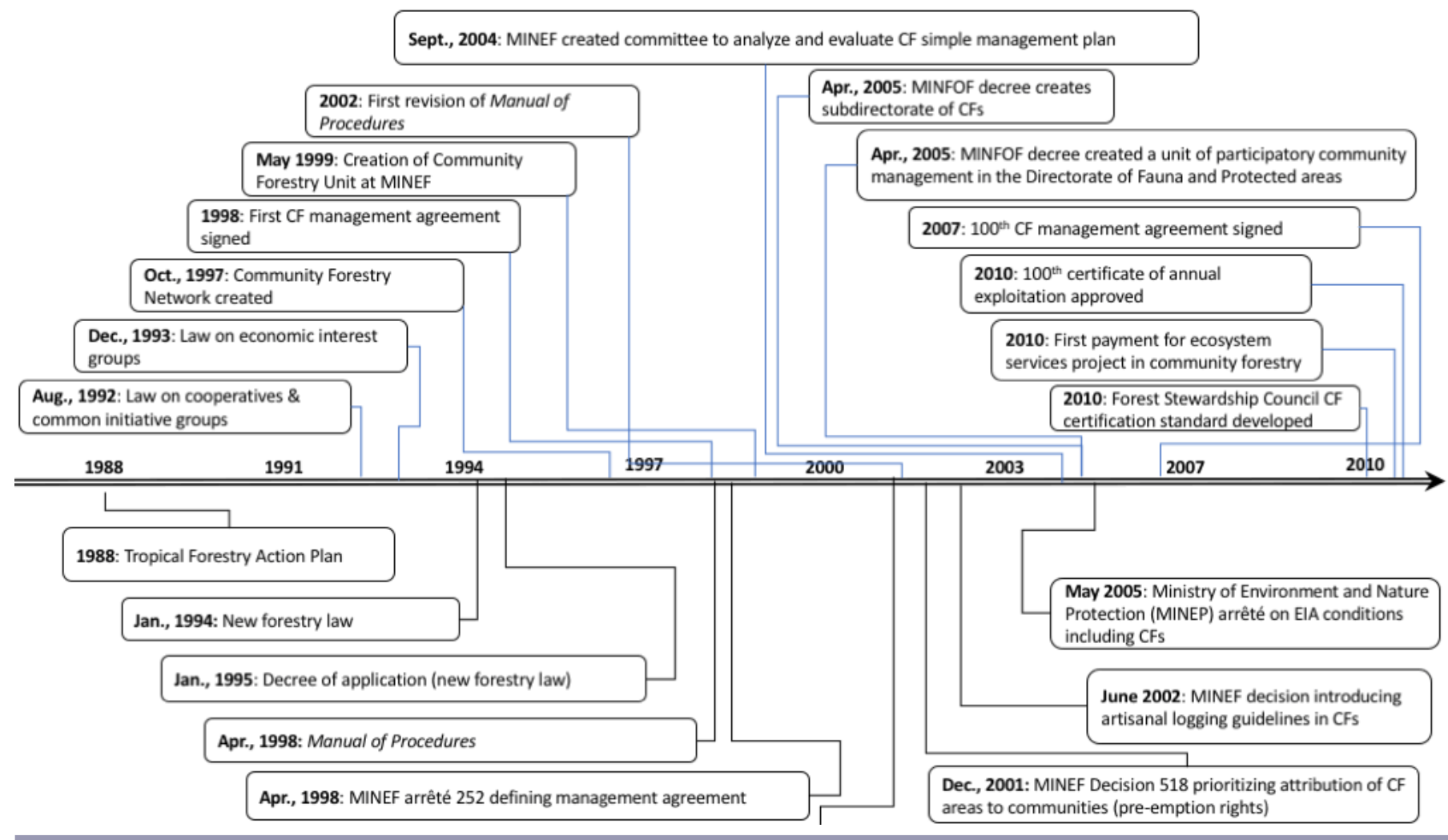

Fig. 2. 2a: Graph showing growth in community forest (CF) numbers; note the positive change immediately following the publication of the Manual of Procedures in 1998. Figure 2b: Evolution of key features in community forestry development; note changes in simple management plan (SMP) growth following issuance of pre-emption rights and temporary management agreements (MA) in 2010.
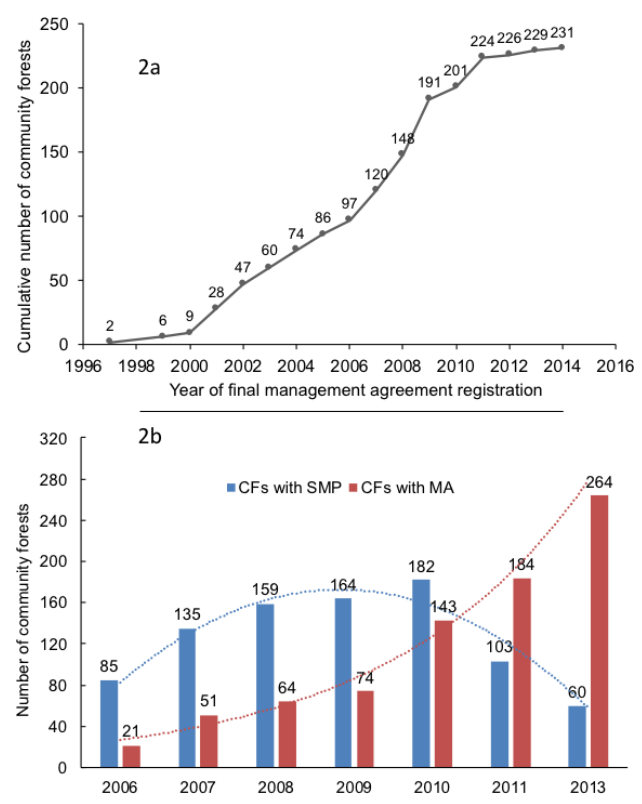

Fig. 3. A representation of the community forestry (CF) innovation ecosystem in Cameroon.

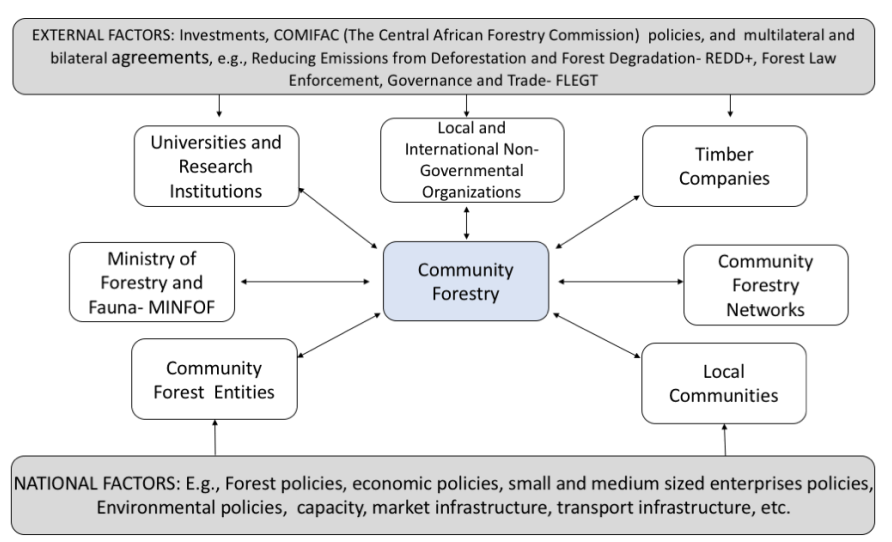

keep a more or less up-to-date digital database of community forestry with details such as shape files of each, the status of the $\mathrm{CF}$, its area, etc. They are also in charge of monitoring compliance of all sorts, including approval of management plans, management agreements, monitoring implementation, and sanctioning any noncompliance. The subdirectorate for CF remains very small and does not necessarily have a visibly clear operational budget hence it is unlikely to be effective in overseeing the implementation of the close to 1.7 million ha of community forests. 
Table 1. Summary of roles and responsibilities of key community forestry actors. Note: $\mathrm{CF}=$ community forestry; MINFOF = Ministry of Forestry and Wildlife.

\begin{tabular}{|c|c|c|}
\hline Actor & Role and Responsibilities & Indicative Impact Description \\
\hline CF Entities & $\begin{array}{l}\text { Legal entities constituted to apply for and manage community forests on behalf of } \\
\text { communities. Mostly associations and common initiative groups. A few cooperatives } \\
\text { and economic interest groups. }\end{array}$ & \\
\hline Local Communities & $\begin{array}{l}\text { Creators of demand for community forests, main users of community forests, and } \\
\text { primary beneficiaries of community forests. Mostly riverine communities. }\end{array}$ & \\
\hline MINFOF & $\begin{array}{l}\text { Oversees community forestry law implementation, policy formulation, approval, } \\
\text { facilitation, and monitoring. The Subirectorate of Community Forestry has direct } \\
\text { responsibility in collaboration with subnational level units at the regional, divisional, } \\
\text { and subdivisional levels. }\end{array}$ & \\
\hline $\begin{array}{l}\text { International and Local } \\
\text { NGOs }\end{array}$ & $\begin{array}{l}\text { Principal facilitators of implementation and capacity building on the ground. They } \\
\text { also carry out considerable advocacy work and mobilize tremendous amounts of } \\
\text { money for community forestry work. }\end{array}$ & $\begin{array}{l}\text { Lobbied hard for several changes } \\
\text { in legal and policy framework of } \\
\text { CF. }\end{array}$ \\
\hline $\begin{array}{l}\text { Community Forestry } \\
\text { Networks }\end{array}$ & $\begin{array}{l}\text { Main CF network is primarily focused on advocacy and lobbying, knowledge } \\
\text { generation, and capacity building. Another specific network called Africa Women's } \\
\text { Network for Community Management of Forests (REFACOF) has been focusing on } \\
\text { gender and other livelihood issues around CF. }\end{array}$ & $\begin{array}{l}\text { Lobbied hard for several laws and } \\
\text { regulations. }\end{array}$ \\
\hline Timber Companies & $\begin{array}{l}\text { Timber company roles span a broad spectrum from investors in CF processes to } \\
\text { exploiters of community forests through agreements with communities. They also } \\
\text { sometimes play a key forestry training role for locals when both exchange during } \\
\text { operations through learning-by-doing. }\end{array}$ & \\
\hline $\begin{array}{l}\text { Universities and } \\
\text { Consultants }\end{array}$ & $\begin{array}{l}\text { They provide analytical services to both government, civil society, and communities as } \\
\text { needed. They also generate knowledge, provide training, and facilitate knowledge } \\
\text { exchange. }\end{array}$ & $\begin{array}{l}\text { Influence thinking through reports/ } \\
\text { publications. }\end{array}$ \\
\hline
\end{tabular}

Civil society (NGOs and community-based organizations) have been extremely active in the community forestry sector (Minang et al. 2007a, Movuh 2012). They have mobilized tremendous amounts of money for operationalization and implementation of $\mathrm{CF}$ activities. Early investments supported CF application processes, whereas more recent projects have attempted to support operationalization (MINEF 2003, Cuny 2011). They have also played a big role in lobbying for laws and actions related to user rights, etc. International and local NGOs have teamed-up on advocacy efforts through the Community Forestry Network that was created in 1997. The CF network and civil society in general were very influential in the development of the Manual of Procedures and other rules around CF in Cameroon.

Local communities have been very effective at taking the opportunity to manage community forests, thus the total number of community forests has grown rapidly over the past decade. However, conflicts have also been rife in community forest enterprise (Ezzine de Blas et al. 2011). A few interesting intercommunity collaborative efforts have been recorded in the East Region in which several CFs have been constituted into cooperatives with the help of NGOs. The case of Cooperatif Agroforestier de la Tri-National (CAFT), in the Ngoila subdivision is a good example (Merlet and Fraticelli 2016). There is no evidence that such pulling together has strengthened capital mobilization and/or joint enterprise of any sort. This kind of bundling would still be desirable going forward. An important element in the communities is the role of elites. In some cases, they constitute a very positive driving force whereas in several cases elite takeover and control has also been reported (Mvondo 2006, Oyono et al. 2006, 2007, Piabuo et al. 2018).
Timber companies are by far the strongest links between community forests and the private sector. Often involving some kind of contract for offtake of timber with an element of prefinancing and or technical support in extraction (Ezzine de Blas et al. 2009, Cuny 2011). There has been lots of criticism of these arrangements, often arguing that they bring little benefits to communities (Ezzine de Blas et al. 2009, Cuny 2011). This relationship has not evolved very much. Evidence of private sector linkages to community forestry on the nonwood forestry subsector is scarce.

Universities and consultants have been very active in the $\mathrm{CF}$ subsector by conducting research and assessments that informed decision-making processes both at the community forest management level and also at the national level, especially when the revisions of relevant laws and policy instruments were done. For example, research and development institutions such as World Resources Institute (WRI) collaborated with MINFOF to create the monitoring platform that currently hosts the database of $\mathrm{CF}$ in Cameroon.

\section{Knowledge and information provision}

Innovation demands the successful introduction of novel ideas, hence knowledge and/or sources of information on potential innovations are crucial to the process (Rogers 1995, Rametsteiner and Weiss 2006). In Cameroon, three main sources of knowledge and information were identified: published materials; training; and knowledge in tertiary institutions, e.g., universities, colleges, and research institutions.

We found about 100 publications, of which 55 were peer reviewed and 45 were gray literature (see Figure 4 a for overall description 
Fig. 4. 4a: Distribution of types of publications on community forestry (CF); Figure 4b: Evolution of publication types over the last 20 years; Figure 4c: Evolution of thematic attention in community forestry over the last 20 years.
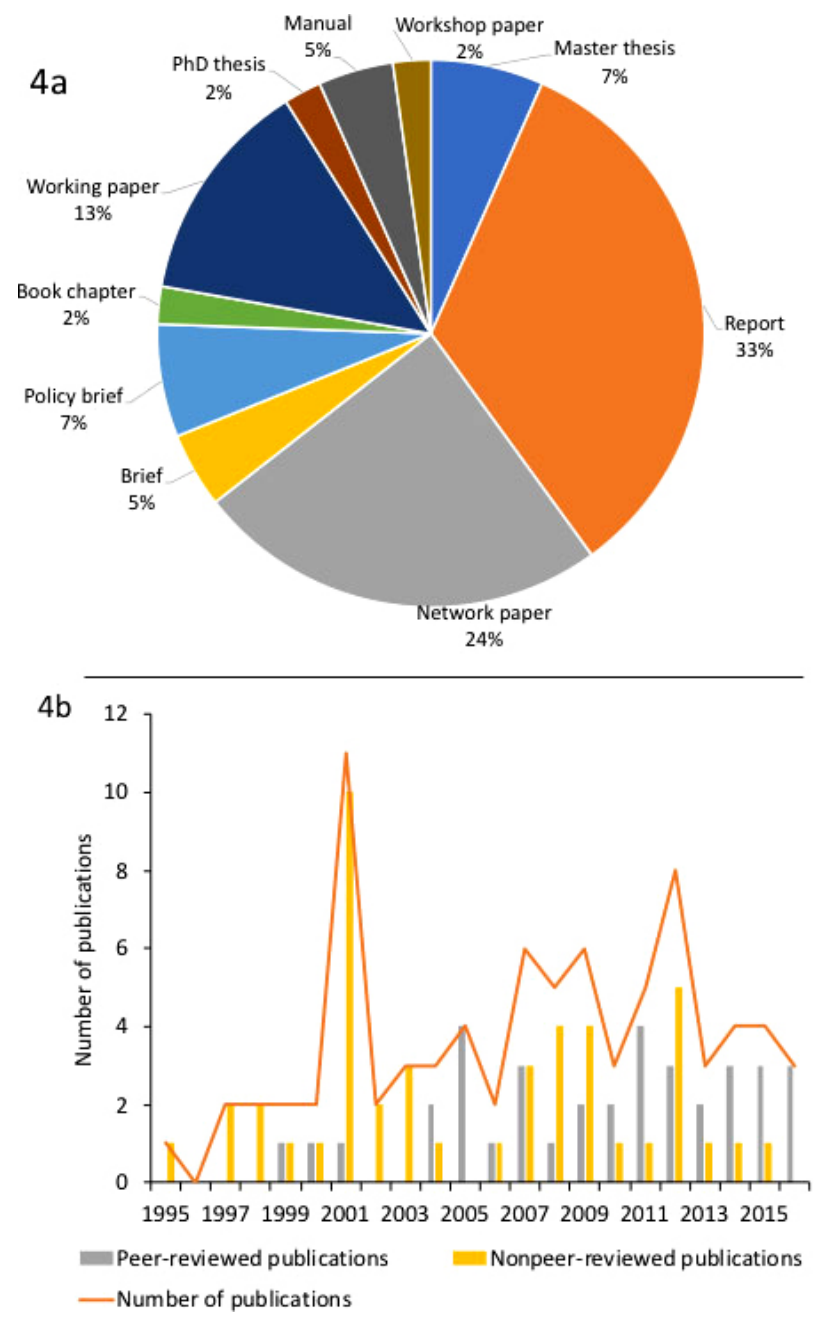

of publication types). As per the databases we used, peer-reviewed literature emerged in 1999, five years after the birth of community forestry and reached peaks in both 2005 and 2011. The number of peer-reviewed publications evened out between 2013 and 2016. Nonpeer-reviewed literature has been more erratic with peaks in 2001 (largely influenced by a special set of papers published by the Overseas Development Institute), 2007, and 2012 (see Figure $4 \mathrm{~b})$. In terms of themes, two sets of related themes top the list. First, a set of papers around institutions, governance, and laws have been consistently present through the history of CF. In second place are papers around participatory processes, transparency, and benefit sharing mechanisms. On the other hand, impact seems to have received relatively little attention. Specific areas for which relatively little impact work has been done are environment, livelihoods, poverty, and rights. Enterprise development and ecosystem services within community forests have also not received much attention. Figure $4 \mathrm{c}$ shows the coverage of themes in the community forestry literature in Cameroon. See also Duguma et al. (2018) for a more detailed analysis.

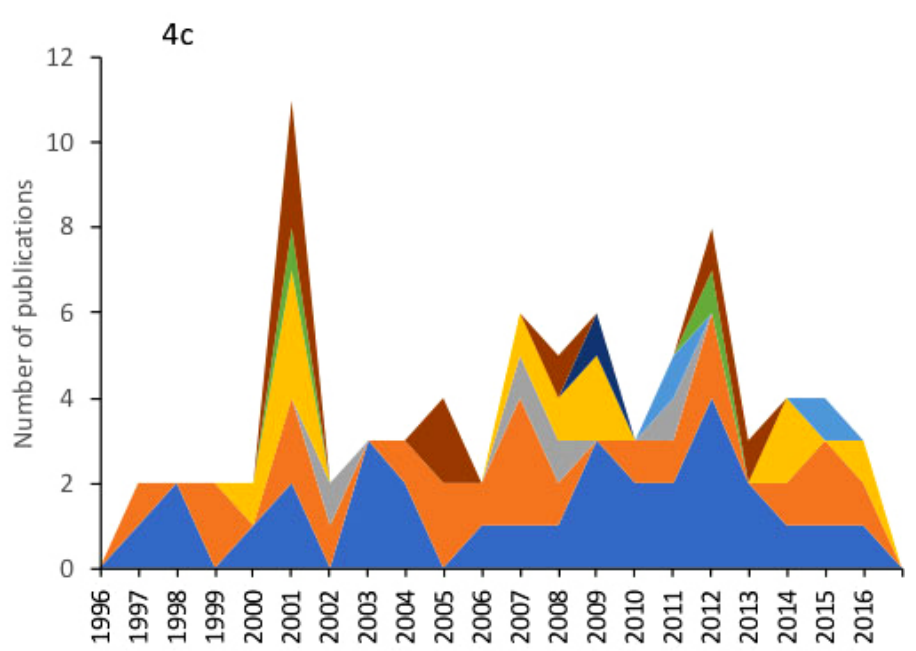

Impact in general

- Impact on rights and benefits of local communities

Impact on environment

Impact on livelihoods and poverty alleviation

Enterprise dynamics - value chains

nanagement capacity, skills, knowledge (local level)

- Participatory processes, transparency, benefit sharing mechanisms, gender, equity (local level)

- Institutions, governance, processes, legal and policy aspects (national level)

Three main institutions directly provide knowledge and training on forestry related topics. Centre Régional d'Enseignement Specialisée en Agriculture (CRESA Forêt-Bois) directly provides training on participatory forest resources management and also on wood processing although we find little evidence that this is applied in CF. The University of Dschang offers courses on general forestry and the University of Ngoundere offers training on food processing relevant for nontimber forest products management in community forestry.

\section{Project actions and initiatives}

Projects have constituted the main innovation vehicle as well as the main channel of resource flow into community forestry in Cameroon, e.g., bilateral and multilateral donor investments in CF through projects (MINEF 2003, Cuny 2011). We identified about 22 projects that have been implemented in the area of community forestry across the country over the last 20 years at varied scales, mostly at multiple sites and at the national level (see Table 2 for a rough distribution of projects across the national territory). The distribution of projects and investments has largely 
Table 2. Examples of community forestry projects and initiatives.

\begin{tabular}{l}
\hline Project name \\
\hline Financing Sustainable \\
Community Forests Enterpr \\
in Cameroon \\
Kilum-Ijim Mountain Forest \\
Project \\
Bamenda Highlands Forest \\
Project \\
The Campo-Ma'an Project \\
(Kudu-Zombo Programme)
\end{tabular}

(Kudu-Zombo Programme)

Coastal Forests Programme,

Cameroon

The Jengi Project, Cameroon

Achieving Conservation and Improving Livelihoods through the Sustainable Management of Community-Based Forest

Operations in Cameroon

Le Projet Développement des Alternatives Communautaires à l'Exploitation Forestière Illégale, Phase 2 (DACEFI 1 \& 2)

Increasing Effective Forest Law Enforcement, Governance and Trade in the Congo Basin of Cameroon (FLEGT)

Partenariats pour le

Développement des Forêts Communautaires (PDFC)

Promotion of Production and

Legal Exportation of Timber that Originates from Community Forests (PEL-FC)

Community Forestry; Payment for Environmental Services Project

Foresterie Communautaire pour Lead: Catholic Relief Services Combattre la Pauvreté (FCCP)

\author{
Partners
}

(ICRAF) (ERUDEF)

Lead: Birdlife International

Programme (UNDP)

Lead: Birdlife International

Programme (UNDP)

Others: (MINEF)

Lead: Rainforest Alliance

Others: de ses Ressources (OPFCR) Cooperation (SNV),

(MINFOF) Cameroon

Lead: Nature + SNV-Cameroon.

Lead: Jeunes et Désœuvrés (CIFED/ APIFED) Development (CED)

\section{Donor(s) and \\ Indicative Financing}

Lead: World Agroforestry Centre

Others: TMP Systems, Centre d'Appui aux Femmes et aux Ruraux (CAFER), Coopérative AgroForestière de la Trinationale (CAFT), Cameroon Ecology (CAMECO), Environment and Rural Development Foundation

Others: United Nations Development

Others:United Nations Development

Lead: World Wildlife Fund (WWF)

Ministry of Environment and Forestry

Lead: World Wildlife Fund (WWF)

Lead: World Wildlife Fund (WWF)

Cercle de Promotion des Forêts et des Initiatives Locales de Développement (CEPFILD) and Organisation pour la Protection de la Foret Camerounaise et

Lead: World Wildlife Fund (WWF

Others: Netherlands Development

Ministry of Forest and Wildlife

Lead : Fondation Camerounaise de la Terre Vivante (FCTV)/Living Earth,

Others: Gembloux AgroBio Tech and

Others: Centre d'Information et de

Formation pour l'Environnement et le Développement/Appui à l'auto Promotion et Insertion des Femmes des

Lead: Center for Environment and

Others:

Diocese of Batouri through the Commité Diocésain des Activités Socio-Caritatives (CODASC)

evelopment

(DFID)

Facility (GEF)

Facility (GEF)

Fund for the

Environment and

Development in

Cameroon (FEDEC)

Congo Basin Forest

Fund (CBFF)
European Union (EU)

Food and Agricultural

Organization (FOA)

CBFF provided $80 \%$ of the funding

EU/SNV

DFID

Fonds Pays Pauvres

Très Endettés

(PPTE),

contribution of

beneficiaries in kind

Department for Centre, East, Littoral, South, and International South West Regions, Cameroon

Project

Duration

Geographic

Coverage

$2015-2020$

Global Environment North West Region

2001-2004

Global Environment North West Region

The Campo-Ma'an National Park

2003-2006

Southwest coast of Cameroon

South-East Cameroon

Since 1999

Campo - Ma'an and Djoum 2009-2013

Mintom areas of southern Cameroon

Gabon (Minkébé and axe Lopé national parks) and Cameroon (Dja Biosphere Reserve)

The Dja Biosphere Reserve

14 CFs with 55,000 beneficiaries in the East, South, and Center regions

14 community forests within the East 2011-2014 and South regions (Djoum and Yokadouma)

South (Dja et Lobo division) and East (Haut Nyong division) Regions of Cameroon

Batouri, East Cameroon
2010-2011

2006-2011

$-2008$

and

2010-2014

2010-2013 


\begin{tabular}{|c|c|c|c|c|}
\hline $\begin{array}{l}\text { Project "RIGC" (Strengthening } \\
\text { of initiatives of community } \\
\text { management of forest and } \\
\text { wildlife resources) }\end{array}$ & Lead: MINFOF & Fonds PPTE & National territory & \\
\hline Capacity Building Program & $\begin{array}{l}\text { Lead: MINFOF } \\
\text { Others: SNV and } 46 \text { NGOs }\end{array}$ & DFID, SNV & Five regions in Cameroon & $2002-2005$ \\
\hline $\begin{array}{l}\text { Mobilization and Capacity } \\
\text { Building for Small and Medium- } \\
\text { Sized Enterprise Involved in the } \\
\text { Production and } \\
\text { commercialization of NonWood } \\
\text { Forest Products in Central } \\
\text { Africa }\end{array}$ & $\begin{array}{l}\text { Lead: Food and Agricultural } \\
\text { Organization of the United Nations } \\
\text { (FAO) } \\
\text { Others: } \\
\text { Centre for International Forestry } \\
\text { Research (CIFOR), the World } \\
\text { Agroforestry Center (ICRAF), and the } \\
\text { Netherlands Development } \\
\text { Organization (SNV) }\end{array}$ & European Union & $\begin{array}{l}\text { Cameroon (Centre-South-Littoral } \\
\text { Province, North-West Province, } \\
\text { South-West-West Province, and East } \\
\text { Province) and Democratic Republic } \\
\text { of Congo (Kinshasa, Equateur, and } \\
\text { Bas-Congo) }\end{array}$ & $2007-2010$ \\
\hline $\begin{array}{l}\text { Community-Based Forest } \\
\text { Enterprises Project (CBFE) }\end{array}$ & Lead: World Wildlife Fund (WWF) & $\begin{array}{l}\text { European } \\
\text { Commission }\end{array}$ & $\begin{array}{l}\text { Over } 50 \text { community forest enterprises } \\
\text { in four countries: Bolivia, Cameroon, } \\
\text { Panama, and Papua New Guinea. } \\
\text { Jengi, in the southeastern part of the } \\
\text { country, and Campo-Maan, in the } \\
\text { southwest. }\end{array}$ & $2007-2010$ \\
\hline $\begin{array}{l}\text { CoNGOs: NGOs collaborating } \\
\text { for equitable and sustainable } \\
\text { community livelihoods in Congo } \\
\text { Basin forests }\end{array}$ & $\begin{array}{l}\text { Lead: International Institute for } \\
\text { Environment and Development (IIED) }\end{array}$ & $\begin{array}{l}\text { Department for } \\
\text { International } \\
\text { Development } \\
\text { (DFID) }\end{array}$ & $\begin{array}{l}\text { Cameroon, Central African Republic, } \\
\text { and Congo-Brazzaville }\end{array}$ & 2015-2019 \\
\hline
\end{tabular}

respected the distribution of community forests across the country, with the East and South regions dominating (see Table 2). In terms of temporal distribution, the bulk of the projects were implemented between 2005 and 2015. The Community Forestry Development Project (CFDP), Capacity Building Programme, and the Renforcement des Institution pour la Gestion Communautaire des Resources Forestières et Fauniques (RIGC) project are examples of national level projects that supported community forestry development (MINFOF and CARFAD 2006). Early projects targeted awareness raising and policy support, evolving in the early 2000 s to facilitating processes for obtaining community forest management agreements. More recent projects are trying to help with implementation and capacity building.

In terms of investments, we only found financial information (i.e., grant sizes or project investment value) for half of the projects identified (i.e., 11 projects). The total investment value of projects identified amounted to about US\$34 million. We estimate that investments in community forestry projects would be at least double the amount, i.e., US\$70 million since inception. This is based on the number of projects identified and the average grant size for the set of projects.

\section{COMMUNITY FORESTRY INNOVATION PATHWAYS IN CAMEROON}

Three main innovation pathways were identified in the development of community forestry in Cameroon over the past 20 years: namely, improved community rights and participation; shifts toward sustainable management; and legal and institutional innovations.

\section{Community rights (pre-emption rights) and participation}

Community forestry has seen significant progress and change in favor of community rights since the promulgation of the law and its decrees of application in 1995 (Ekoko 2000, Nkenfack et al. 2009, Puabio et al. 2018). The main shift involved the introduction of pre-emption rights in which communities were prioritized in the attribution of potential community forest areas in the face of competition from sales-of-standing volumes and other classic forest licensing options in the same nonpermanent forest estate. The introduction of the order (Arrête No. 0518/MINEF/CAB by the Minister for Environment and Forests on December 2001) giving communities the upper hand should they indicate interest in applying for a community forest in any area earmarked for logging, put an end to competition between logging companies and communities. This unlocked a difficult process for communities that could not meet the tedious application conditions immediately, enabling them to buy time knowing the forest would be available (MINFOF and CARFAD 2006).

The introduction of the provisional management plan alternative for communities (Arrête No. 0518/MINEF/CAB) further allowed communities without the necessary resources to proceed with simple exploitation of forests within a period of two years, for the purposes of raising the necessary resources to develop a simple management plan required for the final management agreement. This amounted to not only recognizing the pre-emption rights, but to legally facilitating and enabling communities to fully benefit from the pre-emption rights provision.

\section{Toward sustainable management}

The ban on industrial logging, through a ministerial circular in February 2001 and the Ministerial Decision No. 1985/D/MINEF/ $\mathrm{SG} / \mathrm{FC}$ prescribing modalities and conditions for logging in community forests, notably artisanal logging, was a landmark for sustainable management of community forests in Cameroon. Previously, community forests could be the subject of sale-ofstanding volumes, hence a venue for industrial logging. Hitherto, allegations of sponsorship of community forests by logging 
Table 3. Options for enhancing community forestry (CF) innovation ecosystem in Cameroon.

\begin{tabular}{|c|c|c|c|c|}
\hline & $\begin{array}{l}\text { Providing Information and } \\
\text { Knowledge }\end{array}$ & Investments (Resources) & $\begin{array}{l}\text { Cooperation and } \\
\text { Partnerships }\end{array}$ & Providing Incentives \\
\hline What? & $\begin{array}{l}\text { Increased generation of } \\
\text { knowledge and information; } \\
\text { Increased absorptive } \\
\text { capacity of knowledge and } \\
\text { new ideas }\end{array}$ & $\begin{array}{l}\text { Increased investments in } \\
\text { community forestry }\end{array}$ & $\begin{array}{l}\text { Enhancing interconnections } \\
\text { between community forests } \\
\text { and with other actors }\end{array}$ & $\begin{array}{l}\text { Breaking inertia and } \\
\text { catalyzing adoption of } \\
\text { innovations (practices, tools, } \\
\text { methods, processes, etc.) }\end{array}$ \\
\hline Who? & $\begin{array}{l}\text { University of Dschang, } \\
\text { Centre Régional } \\
\text { d'Enseignement Spécialisé } \\
\text { en Agriculture, University of } \\
\text { Ngoundere, } \\
\text { intergovernmental } \\
\text { organizations, and } \\
\text { nongovernmental } \\
\text { organizations }\end{array}$ & Private sector, state, donors & $\begin{array}{l}\text { Community Forestry } \\
\text { Network, community } \\
\text { forests, nongovernmental } \\
\text { organizations, private sector, } \\
\text { and government }\end{array}$ & $\begin{array}{l}\text { Ministry of Forestry and } \\
\text { Wildlife, Ministry of Finance, } \\
\text { and Ministry of Small and } \\
\text { Medium-sized Enterprises, } \\
\text { Social Economy and } \\
\text { Handicraft }\end{array}$ \\
\hline How?/Options & $\begin{array}{l}\text { CF market information } \\
\text { systems; short courses in } \mathrm{CF} \\
\text { management and } \\
\text { governance; short courses } \\
\text { on green CF practices; } \\
\text { enhanced research on CFs }\end{array}$ & $\begin{array}{l}\text { Community enterprise } \\
\text { funding schemes; } \\
\text { institutional capacity } \\
\text { building and support; } \\
\text { attracting certification and } \\
\text { REDD+ (Reducing } \\
\text { Emissions from } \\
\text { Deforestation and Forest } \\
\text { Degradation) resources; } \\
\text { increased direct budgetary } \\
\text { support for CF from } \\
\text { domestic resources }\end{array}$ & $\begin{array}{l}\text { Collaboration between } \\
\text { community forests; } \\
\text { collaboration between } \\
\text { community forests and } \\
\text { private sector; } \\
\text { collaboration between } \\
\text { community forests and } \\
\text { government; joint enterprise } \\
\text { models that allow pulling } \\
\text { resources and know-how } \\
\text { together }\end{array}$ & $\begin{array}{l}\text { Reward for innovation; } \\
\text { awards; naming and shaming } \\
\text { poor or bad practices; tax } \\
\text { cuts/breaks; simplified } \\
\text { processes/bureaucracy }\end{array}$ \\
\hline
\end{tabular}

companies as an easier and less costly option for obtaining potential logging areas once management agreements were signed were rife (Ezzine de Blas et al. 2009). Artisanal logging meant potentially less damage to the forest, and potential for a more holistic management including agroforestry as well as participation of communities given that artisanal logging would be more labor intensive relative to industrial logging (Auzel et al. 2001)

Suffice it to mention that even though the ban on industrial logging in community forests has been in place, its legality has been questioned by many. Was a simple circular, intended for internal purposes in the ministry, sufficient to annul a provision in the forestry law (MINFOF and CARFAD 2006)? It can be argued that with the maximum area of community forest capped at 5000 ha for management over a 25 -year period, only $1 / 25^{\text {th }}$ of the area can logically be available for sustainable logging every year (i.e., about $200 \mathrm{ha} / \mathrm{yr}$.). This raises questions about how viable such an area would be for industrial logging per year. Logging an area of 2500 ha (the standard sale-of-standing volume area) upfront in the first year in any community forest would raise serious sustainability questions, hence the logic of the circular letter by the minister.

Secondly, the replacement of the full-fledged environmental impact assessment (EIA) with a simpler environmental impact notice as a requirement for community forestry management activities constitutes another innovation in community forestry. In decree No. 2005/05577/PM of February 2005, community forests were initially required to carry out a complete EIA for all $\mathrm{CF}$ activities. The estimated cost of such an EIA was expected to be about 5 million Central African Franc (XAF) or US\$10,000 for review of terms of reference and validation of the report by the competent authorities, not including costs of doing the EIA on the ground. This significantly adds to the management plan development costs that are already extremely high for communities, i.e., between XAF\$4 million and XAF\$16 million (US\$8000-32,000; Mbile et al. 2009). The arrête on environmental impact notice (No. 00002/MINEPDED of February 2016) puts the review and validation costs for community forests at XAF $\$ 50,000$ and SAF\$100,000 (i.e., US\$100 and US\$200), respectively. This significantly brings down the costs (by at least 230 times) and the complexity of procedures for community forests. The introduction of the environmental impact notice also opened up space for community forests to comply with Forest Law Enforcement, Governance and Trade (FLEGT) rules and hence the corresponding opportunities for timber exports.

A third innovation in the sustainability realm is the development and adoption of certification standards for community forest initiatives in 2010 by the Forest Stewardship Council and partners (FSC 2010). The standard is a national standard for certification of high conservation value, biodiversity, and nontimber forest products in community forests and slow or low intensity managed forests in Cameroon. The standard was developed by a group of over 10 civil society organizations led by FSC and a host of local organizations and consultants. There is little evidence as yet that these standards have been used in community forestry and what impact they have created. Nonetheless, their existence indicates a willingness to move the sustainability agenda within community forestry. 


\section{Institutional and legal innovations}

Figure 1 shows a timeline of policy instruments (laws, decrees, procedures, institutions, etc.) that have been instituted in community forestry in Cameroon over the last 20 years. We have reduced the list to those that are very direct and specific to community forestry. The figure shows at least 20 pieces of law, decrees, and orders that govern the community forestry sector. From this set, perhaps the most innovative and instrumental to community forests is the Manual of Procedures and norms for the management of community forestry (MINEF 1998). Figure 2b shows that the number of community forests spiked soon after the publication of the manual in 1998. In the years prior to its publication, while the excitement and financing of community forestry was growing, several aspects relating to definitions and procedures remained unclear. The Manual of Procedures brought tremendous clarity. It can be said that it was a huge innovation not only for community forestry, but also for forestry in Cameroon, given that it remains the most detailed document guiding the management of any forest unit in the country. It is also fair to mention that it has been criticized for being onerous, complex, and resource demanding (Djeumo 2001, Mbile et al. 2009, Movuh 2012).

Institutional innovations have included progressive growth in the status of CF at MINFOF. By $1995 \mathrm{CF}$ was managed by a small unit until it was elevated to a subdirectorate with more powers and responsibilities in 2005 . In addition, there have been attempts at modifying the institutional framework at the community level with suggestions of simplified cooperatives as one form. Changes in institutional forms at multiple levels can potentially change the innovation dynamics within community forestry because it has an impact on the roles and functioning of actors and the rapport between them.

\section{TOWARD AN ENHANCED COMMUNITY FORESTRY (CF) INNOVATION ECOSYSTEM IN CAMEROON}

We discuss what has emerged so far in terms of innovations and propose options for enhancing the $\mathrm{CF}$ innovation ecosystem in Cameroon. Four main areas of potential improvement and corresponding options are: partnership and collaboration, knowledge generation and management, investments, and incentives. Table 3 summarizes these options.

\section{Managing partnerships and collaboration}

Collaboration, partnerships, and networking are indeed crucial for innovation to happen (Mangaoang and Cedamon 2004). Three kinds of partnerships may be relevant: between community forests (e.g., two or more CFs, often in close proximity); between government and community forests; and between private enterprises and community forests (Mayers and Vermeulen 2002). In terms of between community forests a lot needs to be done because little is currently going on. The creation of the Cooperatif Agroforestier de la Tri-National (CAFT) in 2004 was a welcome development in terms of bringing together a set of community forests in the Lomie subdivision in the East Region to collaborate and innovate. After initial years of experimentation in small enterprises, it was clear that timber was a no-go in the area because it created a dependence on logging subcontractors (Merlet and Fraticelli 2016). However, to date few projects have been successfully completed under the CAFT local level cooperation model (Merlet and Fraticelli 2016). Challenges include capital and the absence of model joint-venture arrangements that can be adopted and implemented. The Community Forestry Network needs to be revitalized with a view to enabling intercommunity forest exchanges and substantive cooperation.

So far communities and government maintain minimum collaboration necessary for CFs to function. This entails issuance of the necessary documentation such as exploitation certificates, way bills, and certificates of origin that allows CFs to operate. Little evidence of technical and capacity building support to communities was recorded on the part of MINFOF in recent years. However, this could be improved to enhance the transfer of technical skills from MINFOF to communities.

Community forests and private sector cooperation is one that perhaps needs attention. Although they have collaborated, it has been a relationship of unequal power, one which allows timber companies to take the bulk of the profits because they provide lots of technical and financial resources upfront and recoup later (Ezzine de Blas et al. 2009, Cuny 2011, Merlet and Fraticelli 2016). Much more can be done to enhance this collaboration between community forests and private sector especially in relation to financing and technical support (Mayers and Vermeulen 2002, Antinori and Bray 2005). Evidence exists of strong community and NGO partnerships in Cameroon (Minang et al. 2007a, Movuh 2012). These partnerships have been largely responsible for the majority of innovations and would need to be incentivized going forward to power innovations (Piabuo et al. 2018).

\section{Increased knowledge generation and management}

Knowledge generation and sharing are critical conditions for successful innovation in CF (Nightingale 2005, Smith et al. 2005 , Berkes 2009). We found that innovations occurred in areas/ domains for which the greater number of publications emerged, i.e., legal and institutional reforms related to rights and $\mathrm{CF}$ processes (see Figure 4c). This suggests that publications have directly fed the reform process. Coincidentally, areas for which progress is low have also recorded little or no publications, e.g., enterprise development and/or impact on livelihoods. More knowledge and information would be needed on viable $\mathrm{CF}$ business models, risks, and uncertainties if private investors have to finance community forests (Beuachamp and Ingram 2011, Bakouma and Sève 2012). More importantly, incorporating CF into mainstream natural resource management (NRM), forestry, and economics curricula might help. Specialized CF management courses might also catalyze innovations. Specialized short courses on community forestry of the kind offered by the Centre for People and Forests (RECOFTC) in Asia (see https://www.recoftc. org/) are a good example. Sitoe and Guedes (2015) demonstrated evidence on the role of training as a key incentive for community forestry in Mozambique. Nightingale (2005) also demonstrated that knowledge transfer and sharing on forest management between forestry technical staff and community traditional localknowledge experts was beneficial for CF management in Nepal.

\section{Enhanced investments}

Increased investments, both in terms of capital and capacity building, can help drive innovation in community forests (Ojha and Kanel 2005, Baynes et al. 2015). Current investments are largely from overseas development assistance. There is a need to attract private investments, e.g., from banks and perhaps impact investors into the $\mathrm{CF}$ subsector. Given that all actors are small 
and risk levels are relatively high, there might be a need for government to consider some kind of mechanism for financing or derisking $\mathrm{CF}$ enterprises and/or to act as guarantor to enable private investments (Bakouma and Sève 2012). Sitoe and Guedes (2015) cited investments and diversification of revenue sources as important incentives for maintaining community forests in the long term.

Joint fundraising is also an option. For example, timber operations by single community forests may not be viable because they are small, given the maximum size of 5000 ha. However, two or more community forests that come together could increase viability of the business case for timber in community forests, thereby attracting investments. Research is needed to demonstrate the viability of timber joint-venture options.

\section{Incentives}

Incentives, though necessary, have not been prominent in the $\mathrm{CF}$ innovation landscape in Cameroon. Incentives refer to anything that can motivate an agent to take a particular course of action (Casey et al. 2006). Although the entire CF scheme was designed perhaps as a policy incentive, there has been little in terms of financial and nonfinancial incentives within CF. The single most recognizable incentive was the pre-emption rights, followed by the granting of rights to exploit under a temporary management agreement to fetch enough resources to allow for the development of simple management plans. The expected result then should have been growth in the number of simple management plans. However, Figure $2 \mathrm{~b}$ shows that although the number of provisional management agreements kept growing, the number of management plans started declining compared to the preprovisional management agreement years. This suggests that the incentive did not succeed in catalyzing more management plan developments and therefore more activity in community forests. This also suggests that finances are important but not sufficient to move community forests forward. Well-designed, rights-based incentives have proven to be effective in community forestry in the past (Adhikari et al. 2014).

Most recently, reducing emissions from deforestation and forest degradation (REDD+) and payments for ecosystem services (PES) have been cited as potential incentives for CF development in Cameroon and elsewhere (Minang et al. 2007b, 2014, Newton et al. 2015). Certification has also been cited as a potential pecuniary incentive for community forestry (Wiersum et al. 2013), with FSC developing specific standards for CF in Cameroon. With both REDD+ and certification as potential incentives, serious challenges would have to be overcome to make it work, including chiefly, participatory monitoring capacity, top quality global level management standards, and a safeguards framework that is adapted to local realities. Piabuo et al. (2018) suggests a set of incentives for community forestry in Cameroon in the context of good governance including training and capacity building, awards, direct benefits in terms of wages from employment, and financial incentives such as tax breaks, soft loans, and cost sharing, etc.

\section{CONCLUSIONS}

We set out to investigate, review, and reflect on how community forestry has evolved with a view to seeking ways of enhancing the functioning of the CF innovations ecosystem. Judging by the evidence summarized in Figures 1-4 and in Table 2, interest and momentum in community forestry in Cameroon has remained high. Project activities on the ground remain high, with $\mathrm{CF}$ numbers growing, reaching 430 and covering an area of about 1.7 million ha (almost $7 \%$ of all forests in the country). Knowledge generation in community forestry has been satisfactory, albeit in specific areas.

Although CF innovation ecosystems have evolved and innovated sufficiently in terms of legal and institutional frameworks, and processes for accounting for sustainability and protecting community rights, inertia has been observed in terms of enterprise development, value addition, overall livelihood benefits (with a few exceptional cases), and sustainable forest management practices. Progress has been recorded in knowledge generation, especially in the areas wherein innovations were seen, however, there is a corresponding dearth in knowledge generation and evidence of collaborative learning in domains wherein inertia has been observed. Therefore, knowledge partnership-type activities such as joint fundraising, conflict resolution, problem solving, and capacity development need attention and investments.

Developing innovative enterprises would be critical for sustaining $\mathrm{CF}$ as external support dwindles. This typically needs private sector know-how, skills and investments, new knowledge, training, and market information systems delivered by educational and civil society partners, as well as supportive taxation, subsidies, and simplified bureaucracy led by the respective government departments. This illustrates the kind of synergy between coinvestment, cooperation, and coordination among all actors and from local to national as well as between practice and policy, that would be required for meaningful innovation in community forestry going forward.

Partnerships and collaboration need to be enhanced particularly between community forests. This will enable efficiencies in joint actions and improved potential for leveraging financing, marketing, value addition, networking, certification, and others. Financial and nonfinancial incentives would be needed to foster such collaboration, joint learning, and adaptive management. Many lessons exist from elsewhere in this regard.

Research and analysis on effective, efficient, and equitable mechanisms for facilitating such coordination, cooperation, and coinvestment is therefore a priority for enhancing the functioning of community forestry innovation ecosystems in the future.

\section{Responses to this article can be read online at: http://www.ecologyandsociety.org/issues/responses. php/10573}

\section{Acknowledgments:}

This paper is produced as part of the outputs for the project Financing Sustainable Community Forest Enterprises in Cameroon funded by UK Aid Department for International Development. We are also grateful to the two anonymous reviewers whose comments greatly improved the paper. Special thanks to Judith Nzyoka for editing and support. 


\section{LITERATURE CITED}

Adhikari, S., T. Kingi, and S. Ganesh. 2014. Incentives for community participation in the governance and management of common property resources: the case of community forest management in Nepal. Forest Policy and Economics 44:1-9. http:// dx.doi.org/10.1016/j.forpol.2014.04.003

Agrawal, A., A. Chhatre, and R. Hardin. 2008. Changing governance of the world's forests. Science 320:1460-1462. http:// dx.doi.org/10.1126/science.1155369

Arnold, J. E. M. 2001. Forests and people: 25 years of community forestry. Food and Agriculture Organization of the United Nations, Rome, Italy. [online] URL: http://www.fao.org/ docrep/012/y2661e/y2661e00.htm

Antinori, C., and D. B. Bray. 2005. Community forest enterprises as entrepreneurial firms: economic and institutional perspectives. World Development 33(9):1529-1543. http://dx.doi.org/10.1016/j. worlddev.2004.10.011

Auzel, Ph., G. M. Nguenang, R. Feteké, and W. Delving. 2001. Small-scale logging in community forests in Cameroon: towards ecologically more sustainable and socially more acceptable compromises. Rural Development Forestry Network paper. Overseas Development Institute, London, UK. [online] URL: https://www.odi.org/sites/odi.org.uk/files/odi-assets/publicationsopinion-files/1224.pdf

Bakouma, J., and J. Sève. 2012. Forest management by community forest enterprises. Private Sector and Development Proparco's Magazine 14:13-15. [online] URL: https://www.cesbc.org/ developpement durable/textes/jbakouma jseve eng.pdf

Baynes, J., J. Herbohn, C. Smith, R. Fisher, and D. Bray. 2015. Key factors which influence the success of community forestry in developing countries. Global Environmental Change 35:226-238. http://dx.doi.org/10.1016/j.gloenvcha.2015.09.011

Beauchamp, E., and V. Ingram. 2011. Impacts of community forests on livelihoods in Cameroon: lessons from two case studies. International Forestry Review 13:389-403. http://dx.doi. org/10.1505/146554811798811371

Berkes, F. 2009. Evolution of co-management: role of knowledge generation, bridging organizations and social learning. Journal of Environmental Management 90(5):1692-1702. http://dx.doi. org/10.1016/j.jenvman.2008.12.001

Casey, F., S. Vikemann, C. Hummon, and B. Taylor. 2006. Incentives for biodiversity conservation: an ecological andeconomic assessment. Defenders of Wildlife, Washington, D.C., USA. [online] URL: https://defenders.org/publications/

incentives for biodiversity conservation.pdf

Charnley, S., and M. R. Poe. 2007. Community forestry in theory and practice: where are we now?. Annual Review of Anthropology 36:301-336. http://dx.doi.org/10.1146/annurev.anthro.35.081705.123143

Cuny, P. 2011. Etat des lieux de la foresterie communautaire et communale au Cameroun. Tropenbos International Programme $\mathrm{du}$ bassin du Congo, Wageningen, The Netherlands. [online] URL: http://www.tropenbos.org/file.php/547/etatsdeslieux-28-12-2011. pdf

Djeumo, A. 2001. The development of community forests in Cameroon: origins, current situation and constraints. Rural development forest network paper. 25b:1-16. Overseas Development Institute, London, UK. [online] URL: https://www. odi.org/sites/odi.org.uk/files/odi-assets/publications-opinion-files/1208. pdf

Duguma, L. A., P. A. Minang, D. Foundjem-Tita, P. Makui, and S. Mandiefe Piabuo. 2018. Prioritizing enablers for effective community forestry in Cameroon. Ecology and Society 23(3):1. http://dx.doi.org/10.5751/ES-10242-230301

Ekoko, F. 2000. Balancing politics, economics and conservation: the case of the Cameroon forestry law reform. Development and Change 31(1):131-154. http://dx.doi.org/10.1111/1467-7660.00149

Essegbey, G. O., and E. Ofori-Gyamfi. 2012. Ghana cocoa industry: an analysis from the innovations system perspective. Technology and Investment 3:276-286. http://dx.doi.org/10.4236/ $\underline{\text { ti. } 2012.34038}$

Ezzine de Blas, D., M. Ruiz-Pérez, and C. Vermeulen. 2011. Management conflicts in Cameroonian community forests. Ecology and Society 16(1):8. http://dx.doi.org/10.5751/ES-03845-160108

Ezzine-de-Blas, D., M. Ruiz-Pérez, J. A. Sayer, G. Lescuyer, R. Nasi, and A. Karsenty. 2009. External influences on and conditions for community logging management in Cameroon. World Development 37(2):445-456. http://dx.doi.org/10.1016/j. worlddev.2008.03.011

Forest Stewardship Council (FSC). 2010. FSC standard for community forests and small and low intensity managed forests in Cameroon. Forest Stewardship Council, Bonn, Germany. [online] URL: https://ic.fsc.org/file-download.fsc-forest-stewardship-standardfor-cameroon-community-forests-and-slimfs.a-1665.pdf

Government of Cameroon. 1993. La politique forestière du Cameroun. Ministry of Environment and Forests (MINEF), Yaoundé, Cameroon. [online] URL: http://extwprlegs1.fao.org/ docs/pdf/cmr159241.pdf

Government of Cameroon. 1995. La politique forestière $d u$ Cameroun: document de politique générale. Ministry of Environment and Forests (MINEF), Yaoundé, Cameroon.

Mangaoang, E. O., and E. D. Cedamon. 2004. Building-up partnerships for community forestry: the ACIAR smallholder forestry project experience. Small-scale Forest Economics, Management and Policy 3:353-362.

Maryudi, A., R. R. Devkota, C. Schusser, C. Yufanyi, M. Salla, H. Aurenhammer, R. Rotchanaphatharawit, and M. Krott. 2012. Back to basics: considerations in evaluating the outcomes of community forestry. Forest Policy and Economics 14(1):1-5. http:// dx.doi.org/10.1016/j.forpol.2011.07.017

Mayers, J., and S. Vermeulen. 2002. Company-community forestry partnerships: from raw deals to mutual gains. International Institute for Environment and Development, London, UK. [online] URL: http://pubs.iied.org/pdfs/9132IIED.pdf

Mbile, P., A. G. Ndzomo, H. Essoumba, and A. Minsouma. 2009. Alternate tenure and enterprise models in Cameroon: community forests in the context of community rights and forest landscapes. Strategy paper. Rights and Resources Initiative, Washington, D. C., USA. [online] URL: http://www.rightsandresources.org/wpcontent/exported-pdf/cameroonenglish.pdf 
Merlet, M., and M. Fraticelli. 2016. Protecting forests, improving livelihoods: comparing community forestry in Cameroon and Guatemala. FERN, Brussels, Belgium. [online] URL: http://www. agter.org/bdf/_docs/fern_forestry_cam-guat_internet.pdf

Minang, P. A., H. T. A. Bressers, M. M. Skutsch, and M. K. McCall. 2007a. National forest policy as a platform for biosphere carbon management: the case of community forestry in Cameroon. Environmental Science and Policy 10:204-218. http:// dx.doi.org/10.1016/j.envsci.2007.01.007

Minang, P., M. K. McCall, and H. T. A. Bressers. $2007 b$. Community capacity for implementing Clean Development Mechanism projects within community forests in Cameroon. Environmental Management 39(5):615-630. http://dx.doi.org/10.1007/ s00267-005-0275-2

Minang P. A., M. Van Noordwijk, L. A. Duguma, D. Alemagi, T. H. Do, F. Bernard, P. Agung, V. Robiglio, D. Catacutan, S. Suyanto, A. Armas, C. S. Aguad, M. Feudjio, G. Galudra, R. Maryani, D. White, A. Widayati, E. Kahurani, S. Namirembe, and B. Leimona. 2014. REDD+ readiness progress across countries: time for reconsideration. Climate Policy 14(6):685-708. http://dx.doi.org/10.1080/14693062.2014.905822

Ministry of Environment and Forests (MINEF). 1998. Manual of procedures for the attribution, and norms for the management, of community forests. Ministry of Environment and Forests, Yaoundé, Cameroon.

Ministry of Environment and Forests (MINEF). 2003. Etats des lieux de la foresterie communautiare au Cameroun. Ministry of Environment and Forestry, Yaoundé, Cameroon.

Ministry of Forests and Fauna (MINFOF) and Centre Africain de Recherches Forestières Appliquées et de Développement (CARFAD). 2006 Bilan des acquis de la foresterie communautaire au Cameroun et definition de nouvelles orientations. MINFOF and CARFAD, Yaoundé, Cameroun. [online] URL: http://awsassets. panda.org/downloads/txt6 rapportbilanacquisforesteriecommunautaire 20080422.pdf

Movuh, M. C. Y. 2012. The colonial heritage and post-colonial influence, entanglements and implications of the concept of community forestry by the example of Cameroon. Forest Policy and Economics 15:70-77. http://dx.doi.org/10.1016/j.forpol.2011.05.004

Mvondo, S. A. 2006. Forestry income management and poverty reduction: empirical findings from Kongo, Cameroon. Development in Practice 16(1):68-73. http://dx.doi. org/10.1080/09614520500450867

Mytelka, L. K. 2000. Local systems of innovation in a globalised world economy. Industry and Innovation 7:15-32. http://dx.doi. org/10.1080/713670244

Newton, P., B. Schaap, M. Fournier, M. Cornwall, D. W. Rosenbach, J. DeBoer, J. Whittemore, R. Stock, M. Yoders, G. Brodnig, and A. Agrawal. 2015. Community forest management and REDD+. Forest Policy and Economics 56:27-37. http://dx. doi.org/10.1016/j.forpol.2015.03.008

Nightingale, A. J. 2005. "The experts taught us all we know": professionalisation and knowledge in Nepalese community forestry. Antipode 37(3):581-604. http://dx.doi.org/10.1111/ j.0066-4812.2005.00512.x
Nkengfack, H., C. Njomgang, and D. Sarpe. 2009. An approach for the evaluation of rural governance in Cameroon: are community forests really forests for the communities? Annals of "Dunarea de Jos" University of Galati Fascicle I. Economics and Applied Informatics 2:85-100. [online] URL: http://www.ann. ugal.ro/eco/Doc2009 2/Nkengfack_Njomgang_Sarpe.pdf

Ojha, H., and K. Kanel. 2005. 25 Years of community forestry in Nepal: a review of fourth national workshop proceedings. Journal of Forest and Livelihood 4:56-60. [online] URL: https://www. forestaction.org/app/webroot/vendor/tinymce/editor/plugins/filemanager/ files $/ 7 . \% 2025 \% 20$ years $\% 20$ of $\% 20$ community $\% 20$ forestry- 2 .pdf

Oyono, P. R., J. C. Ribot, S. Assembe, and P. B. Logo. 2007. Improving decentralized forest management in Cameroon: options and opportunities from ten years of experience. Report. Center for International Forestry Research, Bogor, Indonesia.

Oyono, P. R., J. C. Ribot, and A. M. Larson. 2006. Green and black gold in rural Cameroon: natural resources for local governance, justice and sustainability. Working paper series: environmental governance in Africa. World Resources Institute, Washington, D.C., USA. [online] URL: http://pdf.wri.org/ oyonowri wp22.pdf

Piabuo, S. M., D. Foundjem-Tita, and P. A. Minang. 2018. Community forest governance in Cameroon: a review. Ecology and Society 23(3):34. https://doi.org/10.5751/ES-10330-230334

Rametsteiner, E., and G. Weiss. 2006. Innovation and innovation policy in forestry: linking innovation process with systems models. Forest Policy and Economics 8:691-703. http://dx.doi.org/10.1016/ j.forpol.2005.06.009

Ribot, J. C. 2002. Democratic decentralization of natural resources: institutionalizing popular participation. World Resources Institute, Washington, D.C., USA. [online] URL: https://vtechworks.lib.vt. edu/bitstream/handle/10919/65426/361 ddnr full revised.pdf? sequence $=1$

Rogers, E. M. 1995. Diffusion of innovations. Fourth edition. Free Press, New York, New York, USA.

Sitoe, A. A., and B. S. Guedes. 2015. Community forestry incentives and challenges in Mozambique. Forests 6:4558-4572. http://dx.doi.org/10.3390/f6124388

Smith A., A. Stirling, and A. Berkhout. 2005. The governance of sustainable socio-technical transitions. Research Policy 34:1491-1510. http://dx.doi.org/10.1016/j.respol.2005.07.005

Smorodinskaya, N., M. G. Russell, D. Katukov, and K. Still. 2017. Innovations ecosystems vs. innovation systems in terms of collaboration and co-creation of value. Pages 5245-5254 in Proceedings if the $50^{\text {th }}$ Hawaii International Conference on Systems Sciences. http://dx.doi.org/10.24251/HICSS.2017.636

Wiersum, K. F., S. Humphries, and S. van Bommel. 2013. Certification of community forestry enterprises: experiences with incorporating community forestry into global system for forest governance. Small-scale Forestry 12:15-31. http://dx.doi. org/10.1007/s11842-011-9190-y 